\title{
NILAI-NILAI KEISLAMAN DALAM PERIBAHASA SUNDA UNTUK MENGEMBANGKAN BAHAN AJAR BAHASA SUNDA BERBASIS KARAKTER DI SMP
}

\author{
Achmad Sopian Effendi \\ SMP Negeri I Campaka Kabupaten Purwakarta \\ Pos-el: Achmadsopianeffendi@yahoo.co.id
}

\begin{abstract}
Abstrak
Penelitian ini bertujuan memaparkan nilai-nilai keislaman yang terdapat dalam peribahasa Sunda sekaligus menggali nilai-nilai pendidikan karakter yang terkandung di dalamnya. Peribahasa Sunda merupakan untaian kata-kata idiomatik yang berperan sebagai dasar-dasar pendidikan moral masarakat (Sunda) yang diturunkan dari generasi ke generasi hingga saat ini. Karena perannya tersebut, peribahasa Sunda sarat dengan nilai-nilai luhur bangsa, termasuk di dalamnya terdapat nilai-nilai yang relevan dengan ajaran Islam sebagai agama mayoritas di tanah air. Dalam penelitian ini digunakan metode deskriptif. Untuk memperoleh data digunakan teknik studi pustaka, intuisi (introspeksi), dan elisitasi. Data diolah dengan metode hermeneutik melalui analisis data langsung. Hasil penelitian ini adalah ditemukannya nilai-nilai keislaman pada hampir seluruh peribahasa Sunda, baik itu yang terdapat pada aspek keyakinan (aqidah), tata kehidupan sosial (muamalah), maupun pada aspek sikap dan tingkah-laku personal (ahlak). Dari data tersebut muncul tak kurang dari 94 butir nilai-nilai pendidikan karakter yang bisa dipastikan sebagi nilai-nilai karakter asli bangsa Indonésia yang berbasis budaya dan agama Islam. Nilai-nilai luhur tersebut sepatutnya dijadikan acuan dasar pengembangan pendidikan berkarakter di tanah air.
\end{abstract}

Kata kunci: nilai keislaman, peribahasa Sunda, pendidikan karakter

\section{ISLAMIC VALUES IN SUNDANESSE PROVERBSIN DEVELOPING CHARACTER-BASED SUNDANESSE TEACHING MATERIAL IN JUNIOR HIGH SCHOOL}

\begin{abstract}
This research is aimed to explain the Islamic values in Sundanesse proverbs and reveal the character values containedtherein. A Sundanesse proverb is a series of idiomatic words, which serve as a foundation for moral mass education handed down from generation to generation until now. Because of its role, Sundanesse proverbscontain full of noble values of a nation, including thosein accordance to the Islamic teachings. This research used a descriptive method. The data were obtained by using a library research technique, intuition, and elicitation. The data were analyzed by using a hermeneutic method through a direct analysis. Results indicate that the Islamic values are found in almost all the Sundanesse proverbs, i.e. inthe creed aspect (aqidah), social life (syariah), and behavioral aspect (ahlak). More than 94 original character (Islamic and cultural) values of Indonesia emerge from the data. Such values should be the reference points in develoving character-based education in our country.
\end{abstract}

Keywords: Islam values, Sundanesse proverbs, character building 


\section{PENDAHULUAN}

Paling tidak ada dua hal pokok yang tak pernah luput dalam persoalan pendidikan sepanjang perjalanan sejarah, yaitu upaya pewarisan nilai-nilai budaya yang merupakan bentuk tertinggi dari karya cipta peradaban manusia, dan penanaman nilai-nilai spiritual sebagai landasan dasar penguatan sisitem keyakinan yang berada dalam wilayah supranatural. Keduanya merupakan material dasar yang saling mempengaruhi satu sama lain dan menjadi unsur terbentuknya sebuah peradaban yang luhur. Bilamana salahsatunya terjadi kesenjangan akan menimbulkan kepincangan atau bahkan bakal menimbulkan persoalan sosial yang sangat serius.

Dalam konteks pendidikan modern dewasa ini, yang sering menjadi persoalan adalah pola pendekatan pendidikan di tengah kuatnya arus peradaban global menciptakan tingkat kesulitan yang sangat tinggi dalam upaya membentengi nilai-nilai budaya lokal atas pengaruh dan desakan budaya asing. Akhirnya peradaban bangsa terjebak dalam pemikiran post modernisme pendidikan yang jauh berorientasi pada penguasaan ilmu pengetahuan dan teknologi sebagai akibat dari upaya menjawab persaingan global yang terus merebak. Di sisi lain tanpa terasa banyak bangsa yang telah jauh meninggalkan dan mengesampingkan hal-hal yang paling dekat dan yang paling prinsip untuk dipertahankan, ialah penguatan jati diri bangsa itu sendiri. Maka tak heran apabila output pendidikan di tanah air dewasa ini tanpa kita sadari sedikit demi sedikit telah berhasil memisahkan generasi muda dengan budaya dan jati diri bangsanya sendiri.

Paribasa Sunda (pepatah Sunda) merupakan salahsatu local genius yang di dalamnya merupakan sumber pendidikan moral masarakat seperti yang dikemukanan oleh Meider (1993:5) "a short, generally known sentence of the folk which contains wisdom, truth, morals, and traditional views in a metaphorical, fixed and memorizable form and which is handed down from generation to generation". Mengingat perannya sebagai salahsatu sumber ajaran moral, peribahasa Sunda sarat dengan nilai-nilai luhur bangsa, termasuk di dalamnya terdapat substansi dari nilai-nilai keislaman.

Paling tidak ada tiga subsatnasi nilainilai keislaman yang perlu dikembangkan dalam perspektif pendidikan, yaitu aspek kayakinan (credial, credo), aspek ritual (ceremonial), dan aspek prilaku (behavioral). Aspek ajaran Islam yang menyangkut persoalan keyakinan disebut aqidah atau keimanan, sedangkan aspek ritual, norma, atau hukum disebut syariah, dan aspek yang berkaitan dengan masalah prilaku disebut ahlak (Sauri, 2013: 54).

Oleh karena itu, peribahasa Sunda yang sarat dengan nilai-nilai keislaman sangat cocok untuk dijadikan sebagai salahsatu sumber bahan penelitian yang bertujuan untuk menggali nilai-nilai luhur yang bermuara pada nilai-nilai budaya yang berelevansi positif dengan nilai-nilai spiritual keagamaan.

Nilai-nilai luhur pilihan sepatutnya ditransformasikan melalui upaya dan rekayasa kurikulum pendidikan berbasis karakter, dengan demikian hal tersebut diharapkan bisa membantu peran dan fungsi institusi pendidikan sebagai "agent of change" bagi paragenerasi muda (siswa) menuju kearah perubahan yang lebih baik. Melalui pendidikan karakter inilah nilai-nilai budaya dan nilai-nilai agama menjadi ujung tombak pendidikan sehingga paragenerasi bangsa (siswa) memiliki tiga kompetensi karakter utama, yaitu mengenali nilai-nilai kebaikan (knowing the good), mencintai kebaikan (desiring the good), dan mengamalkan kebaikan (doing the good) (Lickona, 1991: 51).

Dalam perspektif pendidikan di tanah air, pendidikan karakter seperti yang dikembangkan oleh Kemendiknas (2010) dinyatakan sebagai berikut. 
Secara psikologis sosial kultural pembentukan karakter dalam diri individu merupakan fungsi dari seluruh potensi individu manusia (kognitif, afektif, konatif, dan psikomotorik) dalam konteks interaksi sosial kultural (dalam keluarga, sekolah, dan masyarakat) dan berlangsung sepanjang hayat. Konfigurasi karakter dalam konteks totalitas proses psikologis dan sosial-kultural tersebut dapat dikelompokkan dalam: Olah Hati (Spiritual and emotional development), Olah Pikir (intellectual development), Olah Raga dan Kinestetik (Physical and kinestetic development), dan Olah Rasa dan Karsa (Affective and Creativity development).

Ditegaskan lagi dalam perspektif filsafat Sunda yang menyatakan bahwa hakikat dari sebuah usaha pendidikan itu bertujuan untuk membentuk manusia yang memiliki catur jatidiri insani, yakni pengkuh agamana (spiritual quotiont), luhung élmuna (intelectual quotiont), jembar budayan (emotional quotiont), dan rancagé gawéna (actional quotiont) (Sudaryat dkk., 2012: 143).

Mengingat hal tersebut di atas, maka penelitian yang berjudul "Nilai-nilai Keislaman dalam Peribahasa Sunda Untuk Mengembangkan Bahan Ajar Bahasa Sunda Berbasis karakter di SMP" ini diharapkan menjadi salahsatu upaya untuk membantu terwujudnya cita-cita mulia tersebut.

\section{METODE}

Metode yang digunakan untuk mendukung penelitian ini adalah deskriptifanalitis atau bisa juga disebut metode etnografi mengingat penelitian ini berada dalam lingkup antropologi budaya. Metode tersebut digunakan untuk mendeskripsikan sumber data yang diperoleh untuk kemudian ditafsirkan melalui proses analisis data. Adapun teknik yang digunakan adalah studi pustaka dengan mengambil beberapa sumber data berupa buku peribahasa sunda yang terbit dalam lima dekade terakhir.
Pendekatan teori hermeneutika Paul Ricoeur yang dipakai untuk mengungkap makna di balik teks paribahasa Sunda hingga menghasilkan beberapa deskripsi penafsiran yang kemudian dikomfrontasi dengan beberapa keterangan dan penafsiran ayatayat suci Al-qur' an beserta hadist Rosululloh sebagai acuan pembanding dalam pendekatan keislaman sehingga memunculkan data yang diharapkan. Data tersebut berupa deskripsi nilai-nilai keislaman dan nilai-nilai pendidikan karakter yang terdapat dalam peribahasa Sunda yang meliputi aspek keyakinan (aqidah), aspek ritual, norma, atau hukum (syariah), dan prilaku (ahlak).

\section{HASIL DAN PEMBAHASAN}

Dari penelitian ini sekurang-kurangnya terdapat dua temuan penting, yaitu (1) berkenaan dengan nilai-nilai keislaman yang terdapat dalam peribahasa Sunda dan (2) berkenaan dengan nilai-nilai pendidikan karakter yang terdapat dalam peribahasa Sunda yang mengandung nilai-nilai keislaman.

\section{Nilai-Nilai Keislaman dalam Peribahasa Sunda}

Dari 367 peribahasa Sunda, tidak ditemukan satupun sumber data yang bertolak belakang dengan nilai-nilai keislaman, bahkan hampir semua maksud yang terkandung dalam peribahasa Sunda memiliki kesesuaian isi dengan nilai-nilai keislaman.

Nilai-nilai tersebut tersebar dalam tiga klasifikasi poko ajaran Islam, yaitu aspek keyakinan (aqidah), aspek hukum, norma sosial (syariah), dan aspek hubungan interaksi prilaku manusia (ahlak).

\section{Aspek Aqidah dalam Peribahasa Sunda}

Sistem keyakinan (aqidah) manusia yang tergambar dalam peribahasa Sunda menjelaskan kepada kita bahwa aspek keyakinan manusia Sunda terhadap tuhannya mencakup seluruh aspek kehidupan dan meliputi semua proses daur hidup manusia 
mulai sejak awal penciptaan, tugas dan tujuan hidup, sampai keyakinan akan datangnya kematian, dan bahkan keyakinan atas adanya kehidupan setelah kematian (akhirat).

Sementara itu yang menyangkut eksistensi Tuhan terhadap manusia dan seluruh mahluk-Nya menyangkut tiga hal pokok, yaitu Tuhan sebagai Robb, Dzat yang berarti mencipta, mengurus, mendidik, menentukan (rizki, umur, nasib dsb.) yang berada dalam ruang lingkup Tauhid Rububiyah, Tuhan sebagai satu-satunya Dzat yang berhak untuk disembah, dipuja, sekaligus yang berhaak diminta pertolonganNya yang berada dalam ruang lingkup Tauhid Uluhiyah, dan Tuhan sebagai Dzat satu-satunya yang berhak menghukumi, memberikan aturan kebenaran yang hakiki bagi seluruh mahluk-Nya yang berada dalam ruang lingkup Tauhid Hakimiyah.

Gambaran sistem keyakinan tersebut bisa diuraikan dalam deskripsi data berikut ini.

\section{Dihin pinasti anyar pinanggih}

Segala hal yang dialami ahari ini, hakikatnya sudah ada dalam rencana dan ketentuan Tuhan (QS.057: 022).

Geus aya ti kudratna at. Geus aya ti lohmahpudna

Segala hal yang terjadi sudah tercatat dalam Kitabulloh (QS.057: 022).

Kedua peribahasa di atas menunjukkan sebuah sistim keyakinan bahwa segala sesuatu yang terjadi dalam kehidupan ini adalah sebuah ketetapan Tuhan. Walaupun demikian manusa mengemban tugas untuk sesungguh-sungguh berusaha memenuhi kewajiban hidupnya (apapun itu) dalam rangka beribadat kepada Tuhan Yang Maha Esa dalam setiap takdir hidupnya seperti yang tersebut dalam peribahasa di bawah ini.

Hirup darma wawayangan waé

Manusia hidup mengemban tugas menjalankan lakon hidupnya beribadah kepada Tuhannya (QS. 006: 060).

\section{Hirup ngan saukur ngumbara}

Hidup manusia di dunia hanyalah sebuah pengembaraan, oléh karena itu manusa harus bisa mengumpulkan sebanyak-banyaknya bekal pulang ke kampung halaman yang sebenarnya (akhirat) (QS. 040: 039).

Bahkan usaha atau ihtiar harus dilakukan dengan sungguh-sungguh mengerahkan segenap kemampuan, walau akhirnya yang menyangkut masalah hasil atau tidaknya harus diserahkan sepenuhnya kepada Tuhan, Dzat yang berhak memutuskan segala perkara (tawakal).

\section{Hirup dinuhun paéh dirampés}

Hidup dan mati, hasil ataupun tidak hasil dari sebuah usaha diserahkan sepenuhnya kepada Tuhan (QS. 009: 051).

Manusia diberi kewenangan memilih jalan hidup sesuai dengan pilihannya. Tetapi sangat diingatkan untuk tidak berbuat syirik (menyekutukan Tuhan) seperi yang tersebut dalam peribahasa berikut,

\section{Ulah nyembah kayu batu}

Jangan menyembah dan meminta kepada berhala ( QS. 002: 165).

Perbuatan syirik sangat dibenci Tuhan, sedangkan Dia Maha Tahu atas segala yang dikerjakan oleh manusia walau dilakukannya secara sembunyi atau jauh dari pengetahuan manusia, sebab suatu saat nanti semua amal manusia pasti akan dipertontonkan.

\section{Wong becik ketitik, wong ala ketara}

Keburukan sekecil apapun suatu saat pasti akan terbongkar (QS. 002:072).

Dan Tuhan Yang Mahatahu tidak akan salah menghukumi setiap amal perbuatan manusia dengan seadil-adilnya. Yang salah tak akan tertukar dengan yang benar dan 
Alloh mencitai kebenaran dan membenci keburukan.

\section{Alloh tara nanggeuy di bokongna}

Alloh tidak berpihak pada orang yang salah (QS. 010: 109).

Hidup ini adalah perjalanan menuju kematian, pada akhirnya manusia pasti akan menemui ajalnya. Kehadiran dirinya di alam dunia ini berangkat dari kekuasaanNya, maka iapun pasti akan kembali pada pangkuan-Nya.

\section{Hirup katungkul ku pati}

Hidup ini ditunggu kematian (QS. 003:158).

\section{Mulih ka jati mulang ka asal}

Asal dari Alloh, kembali lagi kepada Alloh (002:156).

Deskripsi di atas menunjukkan bahwa aspek keyakinan (aqidah) yang tergambar dalam peribahasa Sunda meliputi semua aspek kehidupan manusia mulai sejak awal penciptaan hingga kembalinya manusia ke dalam pangkuannya.

\section{Aspek Syariah dalam Peribahasa Sunda}

Nilai-nilai keislaman yang berkaitan dengan masalah syariah terbagi atas dua bagian besar, yaitu (1) aspek ubudiyah dan (2) aspek muamalah. Pada penelitian ini tidak ditemukan adanya peribahasa yang mengatur secara langsung tentang persoalan ubudiyah, terutama persoalan yang menyangkut persoalan ibadah mahdoh seperti yang terdapat dalam syariat Islam (sholat, zakat, puasa, haji, dsb.). Aspek syariah yang terkandung dalam peribahasa Sunda pada umumnya menyangkut persoalan aturan dan norma-norma sosial (muamalat). Hal tersebut menunjukkan bahwa peribahasa Sunda benar-benar merupakan produk budaya yang tidak menyentuh tentang aturan-aturan ceremonial peribadahan yang proporsinya terdapat dalam wilayah kewahyuan (agama), tetapi lebih menekankan pada aspek hukum dan tata kehidupan sosial. Adapun terdapatnya beberapa peribahasa Sunda yang menyinggung masalah sholat, contohnya dalam peribahasa "Ulah poho ka nu lima waktu” lebih cenderung berada dalam wilayah ahlak manusia terhadap tuhannya ketimbang menjelaskan persoalan ceremonial keagamaan.

Peribahasa Sunda yang mengandung nilai-nilai keislaman dalam bidang muamalat dibedakan dalam empat kategori, yaitu (a) aturan tata-cara pernikahan dan kehidupan rumah-tangga (selanjutnya disebut munakahat) (14 \& 20); (b) aturan manusia mengelola urusan ekonomi dan bisnis (selanjutnya disebut muamalat khusus), (3) aturan manusia mengelola persoalan hukum (selanjutnya disebut hukum \& peradilan), dan (4) aturan-aturan manusia mengelola sistem pemerintahan, politik, dan pertahanan.

Pertama, peribahasa Sunda golongan yang mengandung nilai-nilai keislaman di bidang munakahat terbagi pada dua bagian, yaitu: (a) aturan atau etika yang mengatur tentang hak-hak suami yang menjadi kewajiban istri seperti di antaranya adalah hak suami mendapatkan kesetiaan atau pelayanan dari sang istri, yang artinya sang istri berkewajiban untuk setia dan melayani suami (QS.004: 34) seperti yang tercantum dalam peribahasa (14) dan (b) aturan atau etika yang mengatur tentang hak-hak istri yang menjadi kewajiban suami. Seperti di antaranya hak seorang istri menerima nafkah atau dibafkahi oleh sang suami, yang berarti sang suami wajib hukumnya menafkahi sang istri (QS. 002: 233) seperti pada peribahasa (19).

\section{(14) Awéwé mah dulang tinandé} Seorang istri sebaiknya selalu siap melayani suami.

(19) Awéwé mah tara cari ka batawi Seorang istri tidak pergi jauh ke luar mencari nafkah. 
Kedua, peribahasa Sunda yang isinya mengandung aturan bagaimana mengelola urusan ekonomi dan bisnis (muamalat khusus). Secara umum, persoalan muamalat khusus tidak diatur secara rinci dalam ajaran Islam. Selama tidak bertentangan dengan prinsip-prinsip dasar yang terdapat dalam AlQur'an seperti di antaranya yang tercantum dalam QS. 04: 29-30, masalah muamalat dapat berkembang sesuai dengan kondisi dan tuntutan zaman.

Peribahasa Sunda yang mengandung nilai-nilai muamalat khusus terbagi dalam enam kategori, yaitu (a) etika permodalan (26); (b) etika barang produksi (24); (c) etika pemasaran (28); (d) etika transaksi bisnis (29); (e) etika pengelolaan keuangan (30); dan (e) etika pengembangan usaha (33).

(26) Dagang oncom rancatan emas Modal sangat besar, tapi yang dihasilkan tidak seberapa (Q.S. AnNisaa: 29).

(24) Ari diarah supana kudu dijaga catangna

Barang yang dimbil manfaatnya, harus dijaga dengan baik (QS. Al'Araaf : 10).

(28) (Ulah) Dagang pindang ka Cirebon (jangan) Memasarkan barang ke tempat dimana dibuatnya barang tersebut dibuat (QS. Al-Hajj : 46).

(29) Dah bawang dah kapas

Jual beuli sacara kontan.

(30) Duit pait/panas

Uang yang tidak boleh dipakai untuk kepentingan pribadi (QS. AlBaqoroh : 42).

(33) Tani tinggal daki, dagang tinggal hutang

Usaha yang tidak pernah menemui kesuksesan (Q.S. Al-An'am : 132).

Ketiga, aturan atau tata-cara manusia mengelola persoalan hukum dan peradilan. Aspek hukum dan peradilan yang terdapat dalam peribahasa Sunda bisa dibedakan ke dalam dua kategori, yaitu hukum konvensi (sosial) dan tata hukum formal.

Hukum konvensi merupakan norma masyarakat yang tidak tertulis tetapi menjadi acuan dasar pola peri-kehidupan sosial yang dianut dalam masyarakat tertentu. Hukuman yang berlaku bagi pelanggar konvensi sosial berupa hukuman yang bersifat moral.

Dari hasil analisis data, peribahasa Sunda yang mengandung nilai-nilai hukum konvesi terbagi atas empat kategori yaitu (1) etika pengambilan keputusan, (2) etika kataatan hukum, (3) etika kebenaran hukum, dan (4) konsekwensi hukum.

Etika pengambilan keputusan dalam wilayah hukum konvensi masarakat harus didasari oleh kesepakatan umum dan atau hasil musyawarah.

(36) Nangtung di kariungan, ngadeg di karageman

Berkumpul dan bermusyawarah untuk mencapai kemufakatan (QS. Ali-Imron: 159).

Etika ketaatan hukum konvensi berlandaskan pada prinsip-prinsip ketaatan menjalankan hukum dan norma-norma sosial, menghargai hak-hak orang lain, dan satia pada aturan/kebenaran.

\section{(38) Indung hukum bapa darigama}

Taat paada ketentuan hukum negara maupun hukum masyarakat (QS. AnNisaa' : 59).

Etika kebenaran hukum konvensi berorientasi pada penegakan norma-norma sosial dan nilai-nilai kebenaran kontemplatif, seperti yang tercantum dalam peribahasa di bawah ini.

(42) Ari agama téh kudu jeung darigama Aturan agama harus dibarengi dengan aturan yang berlaku dalam lingkungan sosial-budaya masyarakat. 
Konsekwensi hukum sosial merupakan dampak moral yang bisa dirasakan secara langsung (baik-buruknya) sebagai akibat dari perbuatan manusia memperlakukan hukum sosial.

(34) Melak cabé jadi cabé melak bonténg jadi bonténg

Kebaikan akan berbuah kebaikan, demikian juga keburukan akan berakibat keburukan pula (QS. AlQashshosh: 84).

Peribahasa Sunda yang mengandung nilai-nilai keislaman dalam wilayah hukum formal sedikitnya menyangkut dua persoalan dasar, yaitu etika proses peradilan dan etika putusan hukum.

Etika proses perdilan yang terdapat dalam peribahasa Sunda digambarkan dari mulai proses persidangan sampai dengan proses pengambilan keputusan hukum. Dalam proses peradilan setidaknya harus melibatkan tiga pihak, yaitu dua pihak yang sedang saling berurusan dan pihak penengah (hakim atau saksi) seperti yang disebutkan dalam peribahasa di bawah ini.

\section{(46) Adu telu ampar tiga}

Disidangkan, pihak yang sedang berurusan dalam perkara hukum di depan penengah (hakim atau saksi) ( QS. Ali - Imron : 159).

Beberapa prinsip dasar menentukan putusan hukum merupakan prasarat yang harus dikuasai oleh seorang pengambil keputusan hukum (hakim). Hakim harus bisa memutuskan perkara dengan seadiladilnya, dan menghindari sejauh mungkin ketidakadilan. Azas kesamaan hukum harus ditegakkan, hukum tidak tebang pilih, siapapun orangnya bila melanggar hukum harus mendapatkan hukuman yang setimpal seperti yang tersebut dalam beberapa peribahasa di bawah ini.
(51) (ulah) Ayak-ayak béas, пи badag moncor nu lembut nyangsang Menunjukkan proses peradilan yang tidak adil; yang dihukum yang tidak seberapa kesalahannya, sementara yang bersalah (pelaku utama) tidak tersentuh sedikitpun. (QS. An-Nisaa': 58).

Keempat, peribahasa Sunda yang mengandung nilai-nilai keislaman dalam bidang politik, bela negara, dan pemerintahan.

Peribahasa Sunda yang memiliki nilainilai keislaman dalam bidang politik berupa nasihat kepada masyarakat agar berhati-hati dalam memilih pemingpin atau pejabat publik lainnya jangan sampai karena imingiming atau sesuatu hal, kemudian memilih orang yang salah atau memilih orang yang sudah jelas memiliki ahlak (track record) yang kurang baik seperti yang disindirkan dalam peribahasa di bawah ini.

\section{(56) Bilatung ninggang dagé}

Orang yang berperangai buruk tetapi bisa mendapatkan kedudukan basah (Q.S. At-Taubah : 55).

Peribahasa Sunda yang mengandung niali-nilai keislaman dalam bidang bela negara diantaranya ialah peribahasa yang menunjukkan perintah berperang membela negara, bangsa, dan agama, memrintahkan manusia gara memperkuat persatuan, dan perintah selalu hidup waspada terhadap segala kemungkinan (63\&64).

(63) Caringcing pageuh kancing, saringset pageuh iket

Waspada dan selalu siap siaga menghadapi segala macam kamungkinan dan ancaman (QS. An-Nisaa' : 71).

(64) Pageuh kancing loba anjing

Siap siaga dan selalu waspada menghadapi segala macam kemungkinan yang akan terjadi (QS. AnNisaa' : 71). 
Peribahasa Sunda yang mengandung nilai-nilai keislaman dalam bidang pemerintahan di antaranya berisikan perintah kepada para pemimpin untuk memberikan keteladanan terhadap rakyatnya (65), larangan berlaku lalim dan zalim dalam menjalankan tugas kepemimpinannya (70), perintah bersikap adil (72).

(65) Cai di hilir mah kumaha ti girangna Rakyat kecil suka mencontoh prilaku pemimpinnya (QS.Al-Anbiyaa :73).

(70) Ngaraja déwék

Memerintah dengan tangan besi dan kehendak sendiri (raja lalim) (QS. Shaad: 26).

(71) Tugur tundan cutang gantang Kewajiban masyarakat melaksanakan peraturan negara (QS. An-Nisa: 59).

\section{Aspek Akhlak dalam Peribahasa Sunda}

Peribahasa Sunda yang mengandung nilai-nilai keislaman di bidang akhlak dikelompokkan ke dalam enam bagian, yaitu (1) ahlak manusa terhadap dirinya sendiri, (2) ahlak manusa terhadap tuhannya, (3) ahlak manusa terhadap keluarganya, (4) ahlak manusa terhadap orang lain, (5) ahlak manusa terhadap lingkungannya, dan (6) ahlak manusa terhadap waktu.

Pertama, akhlak manusa terhadap dirinya sendiri terbagi atas ahlak dalam bentuk ucapan yang berisikan perintah menjaga kehormatan diri melalui penjagaan lisan, contohnya:

\section{(105) (ulah) Kalapa bijil ti cungap}

Tidak terasa menceritakan rahsiah (aib) diri sendiri kepada orang lain. (QS. Al-Israa' : 53).

Ahlak manusa mengurus dan memperlakukan dirinya sendiri, baik itu menjaga kesehatan (152), berlaku giat dan gesit (84), bisa mengukur keberadaan dan kemampuan diri (89), menghindari hal yang membahayankan dirinya (100), mengurus kecantikan/kebugaran tubuh (89).

\section{(152) Pait daging Pahang tulang}

Kondisi badan yang kuat dan sehat (QS. Al-A'raaf: 31).

(84) Dijieun hulu teu nyanggut, dijieun buntut teu ngépot

Kurang motivasi/semangat (kemauan) dalam berjuang QS. Azzumar: 39)

(100) Iwak nangtang sujén

Menempuh jalan yang beresiko (Q.S. Ann-nisaa : 97).

(89) Geus cueut ka hareup

Sudah tua, sudah lewat usia setengah baya (QS. Al-An'am : 60).

Ahlak manusa terhadap dirinya sendiri dalam hal bersikap (mental):

(75) (ulah) Alak-alak cumampaka (jangan) Meniru-niru gaya hidup orang lain yang kelas ekonomi maupun derajat kehormatannya jauh lebih tinggi dari dirinya (QS. Al-Hasyr: 19).

Ahlak manusa terhadap dirinya sendiri berkaitan pola pikir atau cara pandang. Ada yang menunjukkan sikap rasional (76), selektif (81), pro-aktif (83), dan memiliki etos kerja (104) .

(76) Anjing ngagogogan kalong Mikahayang perkara nu pamohalan ( QS. Albaqoroh: 286).

(81) Ceuli léntaheun

Sadéngé-déngéna sanajan lain déngéunana (QS. Al-Qashosh : 55)

(83) Cukang tara néangan nu ngising Jalma nu butuh pitulung sapantesna datang ka nu rék dipénta tulung QS.An-Najm : 39).

(104) Kajeun panas tonggong asal tiis beuteung

Kajeun capé usaha asal bisa nyumponan bubutuh hirup sacara mandiri (Q.S. Al-An'am : 135). 
Ahlak manusa terhadap dirinya sendiri berkaitan dengan penampilan dan sikap/ prilaku diri (performance dan attitude), diantarannya ialah menampilkan sikap tenang ( 107), sikap sopan dan santun (110).

\section{(107) Kawas anjing tutung buntut Menggambarkan tingkah laku manusia yang gundah gulana tak bisa tenang dalam bersikap karena resah jiwa (QS. Al-Ma'aarij: 20). \\ (110)(ulah) Kawas badak Cihéa (jangan) berjalan seperti orang yang sombong (QS. Al-Furqaan : 63).}

Akhlak manusa terhadap dirinya dendiri berkaitan dengan sikapnya terhadap ilmu. Di antaranya perintah untuk bersikap rajin dalam menuntut ilmu ( 79), perintah mengamalkeun ilmu (85), dan perintah belajar dalam setiap situasi dan kondisi (88).

(79) Bedog mintul mun diasah launlaun jadi seukeut

Walau orang yang kurang pandai dengan belajar tekun dan terusmenerus, pasti suatu saat akan ada bekasnya/hasilnya. (QS. AlInsyiqooq: 6).

(85) Élmu ajug

Ilmu yang hanya dipakai untuk menasihati orang lain tanpa diamalkan oleh dirinya sendiri (QS. Al-Baqoroh: 44).

(88) Euweuh élmu panungtungan

Ilmu itu tidak akan ada habisnya. ( QS. Al-Kahfi : 109).

Akhlak manusa terhadap dirinya berkaitan dengan harta yang dimilikinya. Di antaranya menunjukkan sikap memanfaatkan (mencukupkan) harta yang seadanya untuk memenuhi kebutuhan hidupnya (131) dan harta digunakan untuk membela keselamatan dan harga dirinya (78).
(131) Mébér-mébér totopong heureut Mencukupkan diri atas rizki yang seadanya untuk memenuhi kebutuhan hidup (QS. AlBaqoroh : 155).

(78) Banda tatalang raga

Kecintaan terhadap harta seharusnya tidak melebihi kecintaan terhadap (keselamatan/ kesehatan) diri sendiri (Q.S AlFajr : 20).

Kadua, akhlak manusia terhadap Tuhannya. Akhlak manusia terhadap Tuhannya meliputi sikep bersyukur (172), ikhlas dalam beramal (173), teguh dalam memegang keyakinan (175), bersikap tawakal (176), dan taat terhadap segala perintah-Nya (177).

(172) Asa kagunturan madu, kaurugan menyan putih

Mendapatkan kebahagiaan/ nikmat yang amat besar ( AdDhuhaa: 11).

(173) Clik putih clak hérang

Melakukan sesuatu didorong oleh rasa ikhlas dan penuh kerelaan (QS. Yunus: 105).

(175) Henteu unggut kalinduan henteu gedag kaanginan

Teguh pendirian, tidak gampang terpengaruh orang lain (QS. Huud: 112).

(176) Hirup dinuhun paéh dirampés Hidup dan mati terserah Tuhan, Usaha sudah dilaksanakan semaksimal mungkin, tinggal berserah diri kepada Sang Penentu (QS. At-Taubah : 51).

(177) Trong kohkol morongkol, dur bedug murungkut (jangan) Malas bangun untuk sholat shubuh. 
Ketiga, ahlak manusia terhadap keluarganya. Akhlak manusia terhadap keluarganya terbagi atas empat bagian, yaitu (1) akhlak terhadap orangtua (ibu-bapak), (2) akhlak terhadap anak-anaknya, (3) akhlak terhadap suami/istri, dan (4) kahlak terhadap saudara-saudaranya.

Akhlak manusia terhadap orangtua (ibubapak) di antaranya ialah bersikap mengabdi/ berbakti (179), menghormati (181), dan berusaha tidak menyusahkan orangtuateu nyusahkeun kolot (180).

(179) Taktak moal ngaluhuran sirah Setinggi apapun jabatan anak tetap harus bersikap hormat terhadap kedua orang tuanya (QS. Al-Isro': 23-25).

(180) Ulah nyeungseurikeun upih ragrag

Jangan suka menertawakan atau menyinggung perasaan orang tua (QS. Al-Isro': 23-25).

(181) Gunung tanpa tutugan, sagara tanpa eusi

Cinta dan kasih-sayang orangtua terhadap anak-anaknya tidak terbatas (QS. Luqman: 14).

Akhlak manusia terhadap anak-anaknya meliputi sikap penuh kasih-sayang (187), mengajari/mendidik (188).

(187) Sagalak-galakna macan tara ngahakan anakna sorangan

Sekejam apapun orangtua, pasti tak akan (mau) mencelakai anaknya sendiri (QS. Al-Ahqof: 15).

(188) Téng manuk téng anak merak kukuncungan

Anak mewarisi gen orangtuanya (Al-Hadist).

Peribahasa yang mengatur ahlak suami terhadap istrinya atau sebaliknya meliputi perintah bersikap rukun, seia-sekata (192), saling mencintai, saling menyayangi (194), setia (195), saling menghargai satu sama lain (196), bertanggung jawab (197), dan mengembangkan sikap keterbukaan (198).

(192) Ka cai jadi saleuwi ka darat jadi salebak

Hidup rukun, seia-sekata (QS. AliImron:103, QS. Al-Anfaal: 46).

(194) Kawas gula jeung amisna Hidup intim, saling menyayangi satu sama lain. (QS. Ali-Imron:103, QS. Al-Anfaal: 46).

(195) Nepi ka pakotrék iteuk

Setia sampai hari tua (QS. AtThuur: 21).

(196) Ngéplék jawér ngandar jangjang, miyuni hayam kabiri/hayam jago éléh ku bikang

Suami yang kalah wibawa oleh istri, takluk oleh istri (QS. AlAnfaal:60, QS. ASh-Shof:4).

(197) Nyalindung ka gelung

Suami yang hidup mengandalkan dari hasil usaha istri (QS. AnNisaa' : 34).

(198) Ulah sumput salindung

Harus terbuka, jangan suka merahasiakan suatu urusan kepada suami/istri (QS. Al-Isro’: 53).

Peribahasa Sunda yang mengajarkan ahlak manusia terhadap saudara-saudaranya sendiri di antaranya ialah perintah untuk menjaga silaturahmi walau terdapat perbedaan atau perselisihan (199), bisa menyadari diri bahwa saudara berada dalam satu kolektivitas keluarga (201), menjaga persatuan (202), lebih memprioritaskan kepentingan saudara di atas kepentingan orang lain (205).

(199) Buruk-buruk papan jati

Seburuk apapun keadaan saudara kandung, ia tak akan bisa terpisahkan dengan kita (QS. BaniIsroil: 26). 
(201) Endog sasayang, peupeus hiji peupeus kabéh

Jika salahsatu dari saudara kita melakukan kesalahan, kitapun akan terbawa (QS. Asy-Syu'aro : 214)

(202) Ka cai jadi saleuwi ka darat jadi salebak

Bersikap akur, rukun dengan saudara (QS. Ali-Imron: 103).

(205) Ngawur kasintu nyieuhkeun hayam (jangan) Dermawan terhadap orang lain, pelit terhadap saudara sendiri (QS. Al-Baqoroh : 215).

Keempat, akhlak manusia terhadap orang lain. Akhlak manusia terhadap orang lain terbagi dalam empat kategori, yaitu (a) akhlak dalam ucapan (208); (b) akhlak dalam prilaku (205); (c) akhlak hati (209); dan (d) akhlak dalam konteks pergaulan (221).

(208) Ambek sadu santa budi

Soleh hati, meskipun hati sedang marah masih bisa bertutur kata yang sopan (QS. Al-Furqaan: 63).

(205) (ulah) Adéan ku kuda beureum (jangan) Berpenampilan bagus dengan pakaian hasil pinjam dari orang lain.

(209) (ulah) Asa ieu aing uyah kidul (jangan) Merasa diri paling baik, paling unggul (Q.S. Luqman : 18).

(221) Datang katingali tarang, undur katingali punduk

Datang dan pergi sebaiknya minta pamit dulu kepada tuan rumah ( QS. An-Nuur: 27).

Kelima, akhlak manusia terhadap lingkungannya. Akhlak manusia terhadap lingkungannya terbagi atas tiga kategori, yaitu akhlak manusia terhadap (a) tanah air (291); (b) lingkungan sosial (316), dan (3) lingkungan pekerjaan (353).
(291) Adam lali tapel

Orang yang lupa pada asal-muasal dirinya, lupa terhadap kampung halamannya sendiri (QS. Ibrohim : 35).

(316) Meungpeun carang ku ayakan Pura-pura tidak tahu terhadap kejelekan/kemungkaran yang terjadi di sekitarnya (QS. An-Nahl: 125).

(353) Tungkul ka jukut tanggah ka sadapan

Serius menggeluti sebuah urusan dengan sepenuh hati (QS. AlAn'am: 135).

Keenam, akhlak manusia terhadap waktu. Akhlak manusia terhadap waktu sedikitnya terbagi atas empat bagian, yaitu (a) perintah introspéksi diri (358); (b) perintah untuk memanfaatkan waktu (359); (c) perintah besikap menyesuaikan diri dengan waktu/zaman (362); dan (d) perintah jangn menyia-nyiakan waktu (35).

(358) Ari umur tunggang gunung, angenangen pecat sawed.

Usia sudah tua tetapi pikiran dan keinginannya masih muda (QS. Al-Hasyr : 18).

(359) Bibilintik ti leuleutik, babanda ti bubudak, geus gedé kari makéna Menabung sejak dini, setelah dewasa tinggal menikmatinya (QS. Al-Isro': 29).

(362) Kudu ngindung ka usum ngabapa ka jaman

Segala sesuatu harus disesuaikan dengan tuntutan zaman (QS.AlIsro: 84), QS.Al-mulk:15).

(35) Ulah marebutkeun paisan kosong Jangan memperebutkan sesuatu yang tak ada gunanya. 


\section{Nilai-Nilai Pendidikan Karakter dalam Peribahasa Sunda}

Dari data 368 data yang dianalisis, sekurang-kurangnya muncul 95 butir nilai pendidikan karakter. Butir-butir nilai karakter tersebut diklasifikasikan berdasarkan pola perencanaan kebijakan nasional pembangunan karakter bangsa tahun 20101015 yang menegaskan bahwa karakter merupakan gabungan dari empat bahan, yaitu olah hati, olah pikir, olah raga, sarta olah rasa jeung karsa. Olah hati berkaitan dengan perasaan, sikap, dan keyakinan/keimanan, olah pikir berkaitan dengan proses nalar untuk mencari dan menggunakan pengetahuan secara kritis, kreatif, dan inovatif, olah raga berkaitan dengan proses persepsi, kesiapan, kemampuan meniru, manipulasi, dan menciptakan aktivitas baru yang dibarengi sikap sportivitas, dan terakhir olah rasa dan karsa yang berhubungan dengan kehendak, keinginan, dan kreativitas yang tergambar dalam kepedulian, pencitraan, dan penciptaan kebaruan (Kemendiknas, 2010: 21).

Oleh sebab itu, 95 butir nilainilai pendidikan karakter tersebut diklasifikasikansesuai dengan keterangan di atas menjadi sebagi berikut.

a. Karakter dalama Olah Hati, terdiri atas: (1) bersikap religius ( beriman \& bertakwa), (2) bercita-cita mulya, (3) bertanggung jawab, (4) bijaksana, (5) jujur, (6) amanah (bisa dipercaya), (7) adil, (8) qonaah (merasa cukup), (9) panadai bersyukur, (10) tawakal, (11) sabar, (12) tabah, dan (13) berhati tulus/ ikhlas.

b. Karakter dalam Olah Pikir, terdiri atas: (14) berfikir logis, (15) cerdas, (16) teguh pendirian, (17) kreatif, (18) teliti / analitis, (19) selektif, (20) preventif dan antisipatif, (21) berfikir realistis, (22) cinta ilmu, (23) futuristik dan visioner, (24) reflektif, (25) determinatif, (26) bersikap politis, (27) kosmopolis, (28) matang dalam berfikir, (29) inovatif, (30) inisiatif, (31) kritis, (32) dinamis, (33) demokratis, (34) hati-hati, (35) berfikir, (36) positifdan terbuka, (37) berorientasi ilmu pengetahuan, (38) menghargai waktu, dan (39) mengutamakan etika, moral, dan hukum.

c. Karakter dalam Olah Raga, terdiri atas: (40) bersikap produktif, (41) memberi keteladanan, (42) bersikap tegas, (43) siap siaga, (44) waspada, (45) tangguh, andal, dan berdaya tahan, (46) pantang menyerah, (47) tekun/rajin, (48) bekerja keras, (49) beretos kerja, (50) hidup sehat, (51) berbakti/mengabdi, (52) gesit dan cekatan, (53) kooperatif, (54) panadai bergaul, (55) bersikap terbuka, (56) mandiri, (57) komunikatif, (58) disiplin, (59) tertib, (60) menepati janji, (61) partisipatif, (62) siap siaga, (63) berani, (64) berdaya tahan, (65) berani ambil resiko, (66)bersikap dinamis, (67) hidup sederhana, (68) berani ambil keputusan, (69) berwibawa, (70) sportif, (71) berdaya saing, (72) dermawan, (73) patriotik, (74) tanggap menangkap peluang, dan (75) punya dedikasi dan semangat pengabdian.

d. Karakter dalam Olah Rasa dan Karsa, terdiri atas: (76) setia, (77) rela berkorban, (78) cinta tanah air, (79) mawas diri, (80) rendah hati, (81) penuh cinta kasih, (82) pemaaf, (83) setia kawan, (84) menghargai prestasi/jasa, (85) tenggang rasa, (86) mawas diri, (87) menghargai sejarah, (88) malu berbuat salah/dosa, (89) memiliki kepedulian, (90) cinta keindahan, (91) cinta damai, (92) percaya diri, (93) berhati lembut, (94) bersemangat, dan (95) bersikap ramah.

\section{SIMPULAN}

Peribahasa Sunda mewariskan nilainilai luhur yang tak ternilai harganya, terlebih bila bangsa ini mampu menghargai dan memanfaatkannya untuk kepentingan pembangunan dan masa depan bangsa. 
Nilai-nilai keislaman yang terdapat dalam peribahasa Sunda sangatlah kental. Bila beberapa pendapat yang menyatakan bahwa peribahasa Sunda itu terlahir jauh lebih awal sebelum masuknya ajaran Islam ke Tatar Sunda dapat dibuktikan, maka sebenarnya pandangan dan cita-cita hidup orang Sunda yang tergambar dari peribahasa Sunda sudah kental dengan nilai-nilai keislaman.

Nilai-nilai keislaman dalam peribahasa Sunda meliputi hampir semua aspek kehidupam manusia, kecuali yang menyangkut masalah syariah ubudiyah yang berada dalam wilayah keagamaan mengingat peribahasa itu sendiri hanya merupakan hasil kebudayaan manusia. Aspek-aspek kehidupan tersebut di antaranya ialah:

a) Aspek Keyakinan (aqidah). Keyakinan akan adanya Tuhan yang mencipta, mengatur, memelihara, mendidik, menentukan segalanya (rububiyah), keyakinan akan adanya Dzat yang wajib disembah dan dipinta (uluhiyah), dan keyakinan adanya Dzat satu-satunya yang membuat dan memeberikan hukuman dan peradilan terhadap mahluk-Nya (hakimiyah).

b) Aspek kehidupan sosial (muamalah) yang meliputi: aturan dan etika berrumahtangga (munakahat); etika dalam perikehidupan ekonomi dan bisnis (bertani, berjual beli, jasa dsb.) (muamalat khusus); tata aturan dan hukum (konvensi masyarakat dan hukum publik formal (pidana); tata cara dan etika berpolitik, bernegara, pemerintahan.

c) Aspek perilaku dan interaksi sosial (ahlak) meliputi etika dan aturan berinteraksi dengan diri sendiri; dengan Tuhannya; dengan keluarga ( orang tua, anak-anak, istri/suami, dan saudar); dengan orang lain; dengan lingkungan sekitar (tanah air, lingkungan sosial, lingkungan pekerjaan) dan ahlak manusia terhadap waktu.
Nilai-nilai pendidikan karakter dari peribahasa Sunda yang mengandung nilainilai keislaman sedikitnya muncul sebanyak 95 butir. Hal tersebut menunjukkan kepada kita bahwa sumber budaya bangsa ini (peribahasa Sunda) memberikan begitu banyak nilai-nilai luhur yang bisa dikonversi menjadi nilai-nilai pendidikan yang amat berharga guna membangun masa depan bangsa ini. Selanjutnya butir-butir nilai karakter tersebut diklasifikasikan menjadi empat kategori, yaitu olah hati (spiritual and emotional development), olah pikir (intellectual development), olah raga dan kinestetik (physical and kinestetic development), dan olah rasa dan karsa (affective and creativity development).

Dari temuan-temuan tersebut bisa dijadikan salah satu acuan untuk pengembangan bahan ajar, khususnya bahan ajar mata pelajaran bahasa Sunda berbasis karakter di smp dan pengembangan nilainilai pendidikan karakter pada mata pelajaran lainnya di semua jenjang pendidikan secara umum.

\section{PUSTAKA RUJUKAN}

Kemendiknas. (2010). Desain Induk Pendidikan Karakter. Jakarta: Kementrian Pendidikan Nasional.

Lickona, T. (1991). Educating for Character, How Our Schools Can Teach Respect and Responsibility. New York: Bantam Books.

Meider, W. dkk. (1993). A Dictionary of American Proverbs. Oxford: Oxford University Press.

Sauri, S. (2013). Pendidikan Karakter dalam Perspektif Islam. Bandung: Rizqi Press.

Sudaryat, Y. dkk. (2012)."Reinterpretasi dan Reformulasi Filsafat Pendidikan Sunda dalam Ungkapan Tradisional". Bandung: Laporan Penelitian LPPM UPI. 


\section{UCAPAN TERIMA KASIH}

Penulis menyampaikan rasa terima kasih kepada tim penyunting Jurnal Lokabasa yang telah berkenan memuat tulisan ini. Tidak lupa penulis menyampaikan terima kasih dan penghargaan setinggi-tingginya kepada semua pihak yang telah membantu terlaksananya penelitian ini. 